\title{
Party's Cultural Commodification: The Unelected Executive Candidates from Islam Affiliated Parties in Indonesia's Local Election on Covid-19 Pandemic Situation
}

\author{
Retno Andriati ${ }^{1}$, Irwan Abdullah ${ }^{2}$, Claudia Anridho ${ }^{3}$ \\ \{retno.andriati@fisip.unair.ac.id ${ }^{1}$ \} \\ Anthropology Department, Social and Political Sciences Faculty, Universitas Airlangga, \\ Indonesia $^{1}$, Antropology Department, Cultural Sciences, Gadjah Mada University, Indonesia ${ }^{2}$, \\ International Doctoral Program in Asia-Pacific Studies, National Cheng Chi University,
}

Taiwan $^{3}$

\begin{abstract}
This study emphasizes the forms of the unelected executive candidate from Islam-affiliated parties and what kind of commodification is influenced to their defeat in the election, especially in the Covid-19 pandemic situation. Another point is how are the implications toward their defeat to society's economic and political condition. This qualitative study looked for the data by observation from preparation-activity to the day of Regent election and by indepth interviews to the members of Islam affiliated parties, the members of the campaign team, the executive candidates, and the voters. The data was analyzed by economic anthropology theory. The result shows that the executive candidate from Islam-affiliated parties was unpredictably unelected even though their party won in that certain district where on prevoting survey and mapping they would win. This is mainly because of the work-culture commodification in which the district-level party's leader was negotiated with other parties. The reasons for this kind of commodification are because of: (1) The future candidate which is family member of the districtlevel party's leader (mentioned as putra pangeran) was not supported by the chairman; (2) Economic-business interest for the future of their family; and (3) Money politics which they gave more money to the voters than to their political opposition' party. The implication is the Islam-affiliated party did not give full support for their executive candidates to be elected. This situation also made society feels so disappointed because they hope for a better new local government that can give a better future for society.
\end{abstract}

Keywords: Unelected executive candidates; party's cultural commodification; Islam-affiliated parties; ethnocentrism; economic interest; covid-19; money politics

\section{Introduction}


The election of regents and deputy regents in Indonesia during the COVID-19 pandemic has caused controversy. The candidate for regent from an Islamic-affiliated party in the district as the winning party and the legislative ruler as well as the bearer turned out to have lost the executive candidate. Some argue that the executive candidate from the legislative ruling party in the city/regency then the candidate will win. The Surabaya executive candidate won the Surabaya mayoral election because his party controlled the Surabaya legislature. Surabaya is the traditional base of the national party that controls the legislature, strong solidarity so that the executive candidate wins in the city of Surabaya (CNN, 2020). Others argue that the legislative control of the carrying party is not certain that the executive candidate will win. Various factors contributed to the defeat of the executive candidates. Kampar executive candidates experienced defeat because the movement of the candidate base had not been maximized, the support for party coalitions was not solid, and there was a lack of campaign funds (Amri, 2018). As shown by Zuber and Masykur (2020), even though the candidates for regional heads lost and were disappointed, they still participated in development and recitation activities.

So far, the study of controversy tends to discuss two things. First, the mayoral candidate's victory is because the party carrying or winning the legislature is solid in providing support (CNN, 2020). The legitimacy of the party and its role in winning the regent/mayor candidate is based on transactional and elitist considerations to produce problematic executive candidates (Dwiranda \& Anggoro, 2020). Second, when the carrying party is less than optimal, the movement to capture voter votes and campaign funds is less than optimal, the regent candidate experiences defeat (Amri, 2018). The tendency of the two studies to see that the defeat of executive candidates is only in one political aspect. Whereas cultural and economic aspects are also important to understand to see the defeat of executive candidates from Islamic-affiliated parties. It is important to study the cultural and economic behavior of Islamic-affiliated parties in more depth.

The purpose of this paper is to complement the shortcomings of previous studies on the relationship between various factors supporting the victory and causes of the defeat of executive candidates from the political aspect only. This study focuses on the district-level executive elections, in particular the defeat of the Regent candidate from an Islamic-affiliated party in the executive election. This Islamic-affiliated party won and controlled the district legislature. Socio-cultural and economic factors, especially the work culture of the Islamicaffiliated parties as to the supporting parties, are related to the controversy over the defeat of the executive candidates they carried. At the same time, this study aims to answer the following questions: 1) the controversy over the defeat of the executive candidate from an Islamic-affiliated party as the legislative ruler of the district; 2) factors that become the basis for the defeat of executive candidates from Islamic-affiliated parties; 3) what are the implications of the defeat of executive candidates from Islamic-affiliated parties.

This paper is based on the argument that in Indonesia there are several Islamic affiliated parties, Islamic parties, national religious ideology-based parties, and national parties as executive candidates. There are supporting parties that work alone and that carry out the politics of inter-party cooperation. The defeat or victory of executive candidates is not only due to the history of executive leadership but also to the transformation of economic, sociocultural, and power interests, as well as the work culture of the party. Economic, sociocultural, and power interests underlie the behavior of actors as elites or members of parties and their communities, not on the economic and socio-cultural interests of the community/constituents. The work culture of the party is more dependent on the leadership of its chairman. So far, the work culture of central Islamic affiliated parties, Islamic parties, 
national parties, religious national parties have not carried out evaluation and monitoring and has lacked social control over the work culture of their parties at the provincial and district levels.

The fact is that there has been a defeat of the Islamic party in the general election in Indonesia. Members of Islamic parties have not been thoroughly asked about the experiences and obstacles they face, the ideas they have during the process of activity within the party. The Islamic party lost because religion had many dimensions while politics had a single dimension. Religion as politics thinks of a massive reduction in the meaning of religion (Noer, 1999). The coalition between parties is full of pragmatic practices and transactional politics (in Islam it is called takaluf siyasi) both from non-Islamic parties and Islamic parties (Hawari, 2019). Islamic parties have never won in real legislative elections from the Old Order to the Reformation era because of causal mechanisms related to political decisions made by party agents in past historical events (Riyanto, 2020). The defeat of Islamic parties in its development was not followed by Islamic-affiliated parties because there were Islamicaffiliated parties that won the district legislative elections in Indonesia. This condition affects the defeat or victory of their executive candidates in the regional head elections.

The previous literature review on the representation of women candidates in Brazil was more about the challenges of accessing support for their candidacy. Female candidates have to work hard to compensate for the loss of campaign funds (Gatto \& Teme, 2020). The 20192020 Coronavirus pandemic has increased public confidence in America to trust women leaders more than men. Women leaders pay more attention to public health. Polls show widespread societal discontent with male leaders. Increasing gender equality through the promotion and empowerment of women is a global policy priority in all countries and development institutions (Piazza \& Diaz, 2020).

\section{Method}

\subsection{Type and Scope of Research}

The type and approach of this research are qualitative. Location names and names of Islamic-affiliated parties have been disguised. Research on the defeat of the executive/regent candidate from an Islamic-affiliated party even though this party controls the district legislature. An Islamic affiliated party is a party whose members and accepts members who are not only Muslim but also other religions. Researchers hope that this party research can provide a holistic perception regarding their response to the defeat of their executive candidates. Various changes in work culture seem to have been carried out by the party during the pandemic. The first simultaneous regent/mayor executive election during the pandemic was carried out in Indonesia.

Data were obtained through post-election observations and in-depth interviews with informants. The selected informants were informants from the group of party administrators and members, voters' groups of Islamic-affiliated parties, non-Islamic party voter groups, recitation groups, DPRD groups, losing candidates for regent and deputy, success teams, community leaders. The reason for the informants was chosen with the consideration that their experience during the preparation, implementation, and post-election processes is expected to provide holistic and in-depth qualitative data on the work culture of Islamic-affiliated parties when cooperating with opposing parties on a national basis. In addition, gender and their socio-economic and cultural environment are also considered which researchers consider 
relevant to understanding cases, constraints (individual, group, infrastructure, and structural), and cooperation that reflect the process of winning certain executive candidates and their real support.

\section{Results}

The controversy over the defeat of the executive candidates from the Islamic-affiliated supporting parties who won the 2019 legislative elections at the Regency level are:

\subsection{The Ballots Turn to Vote for Opponents}

Most of the Regency residents are followers of the NU community organization. The meaning is already plural in the thoughts of NU residents that they must obey their NU Imam. Among NU residents, that they are obliged to 'Samina Wato'na'/follow what the Imam says. When the Imam said they had to choose an Islamic-affiliated party, they followed suit, including when the Imam ordered them to choose an opposing executive candidate, they did so. Controversy in society occurred. They were surprised when the candidate for regent/executive from the party carrying the Islam-affiliated party as the winning party for the legislature and the candidate for the regent lost in the regent election. This Islamic-affiliated party is the ruling party that nominates female regent candidates as members of their party, who are also members of the Provincial DPRD. This female candidate is paired with a candidate for deputy regent as a businessman who is very well known to the public. This businessman was formerly the chairman of the national-religious party. The informant explained:

"I and the voters for the female regent candidate and her other representatives are $100 \%$ sure that they will win because until D-2, based on observations, each sub-district chose the female executive candidate and the male representative won. They are the bearers of the party that wins and controls the DPRD. But everyone was shocked, the results of the quick count of the district KPU for our candidates lost badly...sorry not playing, how can you do that. All ask. What is this? Up to $80-95 \%$ of the votes in the sub-districts that support Islamic-affiliated parties have turned around to vote for the opponent...confused...heard... there seems to be a hidden talk between figures in the green pocket area...".

This party regent candidate should have won because of the support of the majority of NU residents in the district. It turned out that this executive candidate lost.

\subsection{The Hidden Transcript of Non-Compliance with the Recommendation of the Chairperson of the Islamic-Affiliated Party}

This female regent candidate received a recommendation from the General Chairperson of the Central Islamic-affiliated Party after this candidate and her team lobbied the General Chair. This recommendation letter turned out to make the chairman of a local Islamicaffiliated party disappointed because his son as the crown prince or 'prince' who was also running for regent did not receive a recommendation from the general chairman. This disappointment made the head of the district party secretly disobey the regent candidate's legitimate recommendation. According to the informant, the son of the regent who did not receive this recommendation was: 
"trade The record of the crown prince, chairman of local parties, is bad, namely his behavior often deviates from Islamic teachings and has become public knowledge. This condition was also known by the General Chairperson of the Islamic-affiliated Party, so the recommendation was not given to the crown prince. Unfortunately, this local party leader paid little attention to the trade records of his son's bad, even though he knew it was due to his economic interests and power and his family's future. The Imam does not fully support the regent candidate from his party. Even though his son cannot lead and his behavior is not good. No plans for what members of their party must do so that their chosen executive candidate wins. His son is disappointed and angry, if he finds out that his father supports the candidate from the party he leads, his son will be even angrier."

Hidden non-compliance with the decision of the party chairperson regarding recommendations to female regent candidates. The informant said:

"Party people became conflicted and broke up, but they were hidden. The winning team and the regent's brother-in-law were not in line with the hidden steps and decisions of the regent. As a party leader, he is dishonest. As a result, the splinter from the winning team and the sister-in-law seem to favor female executive candidates with more experience in politics as members of the provincial DPRD. Even though this candidate is just a 'katut' family, he is the regent's sister-in-law's sister-in-law. There are no family ties to the regent. But he is a legitimate member of the Islamic-affiliated party."

The omission of Islamic-affiliated parties against the winning team movement and the regent's brother-in-law continues to promote female regent candidates and their deputy. However, the chairman and his team also moved in a different direction, namely to their opponents.

\subsection{The strengthening of 'ethnocentrism' has the effect of weakening the internal party}

This condition shows that internal family conflicts about differences in supported executive candidates, strengthen the 'ethnocentrism' of the chairman, each family member, and relative. Although internally the chairman and members of the board have decided to become the party carrying the female candidate, the demolition continues to be carried out in secret. NU residents who have been given Rp. 20,000.00 and Rp. 50,000.00 in the morning (D-2) by a special team of female regent candidates ahead of the regent election. However, the next day (D-1) it turned out that there had been more money being given to the NU residents by a special team of regent candidates from non-Islamic parties assisted by figures from the Islamic-affiliated parties. That's double the money. Of those who were given Rp. 20,000.00, they were given Rp. 50,000.00 and those who were given Rp. 50,000.00 were given Rp. $100,000.00$. This condition was supported by the regent's son who did not receive a recommendation from the General Chairperson by participating in the demolition of his Islamic affiliated party. The informant explained:

"When the female regent candidate found out that more money was being given to her NU supporters, her team said it was okay to the deputy regent candidate and was willing to give more money, but it didn't happen. The deputy regent candidate was lied to. Even in certain sub-districts, which all supported and promised to elect a female regent and a male deputy regent, it turned out that less than $1 \%$ of them voted for them". It's easy to change the members of NU and others because they get more money. They also made a cash approach to recitation figures of Imam and Nyai so that their followers would vote for an opposing candidate from a national party. Checked in the field, it turned out that it was true that there was money given by team members from female regent candidates who joined 
the opposing team and gave money to residents of each sub-district... 50 - 100 thousand on D-1 with the condition that they chose an opposing candidate. Why is it lying... deflating the party itself... There is a process of manipulation... the cooperation is lying together... it's a hassle for the figures to be involved... why is this?"

This approach to money applies to figures in the recitation of Imam and Nyai (respectful term to address older woman) so that their followers vote for a candidate against a national party. This agreement is not known to the special team for winning female regent candidates and their deputy. The factors causing the controversy over the defeat of executive candidates from Islamic-affiliated parties are:

\subsection{Internal Conflicts Between the Regent's Family and Islamic-Affiliated Parties}

The internal conflicts of these local Islamic-affiliated parties were triggered by internal conflicts with the Regent's family. This conflict was triggered by a conflict between 1) the regent and his wife, 2) the regent and the regent's brother-in-law. Each has a different executive candidate. The regent nominated his son. The regent as the father and chairman of an Islamic-affiliated party prefers to finance and approve the nomination of his son. The regent's wife nominated her younger brother but the regent did not approve. As a result, the regent's sister-in-law nominated another relative, namely a woman member of her party who had become a member of the Provincial DPRD. As a result, the sister of the regent's wife increasingly supports the female candidate of the party, which has been recommended by the central general chairman of an Islamic-affiliated party. The suppression of the regent in his own family continues to the slapping of executive candidates from the party he leads himself as well as the supporting party. Internal family conflicts affect increasing differences of opinion and support.

Internal conflicts in the regent's family have an impact on internal party conflicts. Differences of opinion on who to support pushed the administrators and Imam to split into certain groups within the party. Even though this party has decided to nominate a female executive candidate and her deputy. The Islam-affiliated party was further divided when the chairman and his team visited the house of the former regent who also nominated his unmarried son as the candidate for regent of the national party. The chairman of this local Islamic-affiliated party decided without an internal party meeting. According to the informant:

"Islamic-affiliated parties are considered as their own, no matter what the chairman says.

People who are also members are prohibited from objecting. The organizational culture of the party is not working. Because people understand that people enter the party by looking for space to find fortune/jobs. A person should join a party is to learn to organize to help the community in fighting for their aspirations in various social problems that exist in social life. But in reality, almost all members of the ruling party only think about enriching themselves and the people who help them win in the process of making them members of the legislature. So, they are less responsive/critical to the problems that exist in society in general. They are only critical or responsive when there is an interest in maintaining constituents for future elections".

This internal family conflict has an impact on the internal conflict of Islamic-affiliated parties and the loss of their executive candidate.

\subsection{Giving Money From One Door to Another and During the Recitation}


The process of giving money through community leaders and certain trusted people to residents, by saying Indonesian: "I'll choose A later..." or local language/Javanese: "mbenjing choose A... nggih.." Then the money is given to residents in each district. They keep moving from one house to another until the envelopes contain money or the money runs out immediately. They also give money when there are recitations through Imam and Nyai. It turned out that this extra money was also given about two weeks before the D-day. This was explained by the informant whose status was not willing to be mentioned. If their job of giving money to residents is leaked, then they are no longer invited to do business by 'party people'. Some residents know who they are but they don't want to mention it when asked. Residents are also worried that if they are caught telling other people, they are in danger of not getting any more money during the executive election as regent/governor/president and legislative elections as members of the DPR/DPRD. This money-giving movement was carried out carefully and discreetly. Cross-checked with other informants about why there were figures who helped the opponent win, the answer was:

"This chairman pays more attention to big and well-known Imam, given positions, jobs and other facilities, according to his promise when the Imam was campaigning for the election of regents before. This chairman has two terms. This chairman made the village/small Imam hurt and chose the candidate for regent as opposed to this party. The chairman did not keep his promise to the village Imam, even though they helped to get voters' votes, not only NU residents but also citizens so that he was elected. They are forgotten by the chairman."

\subsection{Half-Hearted}

Support This half-hearted support of Islamic-affiliated parties was seen during an internal meeting with the party chairman who said he fully supported it. In practice, there are no direct instructions and actions for the management and their team to carry out a vote to support the people in choosing the executive candidate promoted by their party. Disappointed that the regent did not receive a recommendation for his son, he and his team half-heartedly supported the executive candidate from the Islam-affiliated party he led even though this party was the supporting party. The regent's son is angry when he doesn't get a recommendation, this anger continues if his father supports the regent candidate from the party he leads. His father as party leader chose to support the opponent. Meanwhile, the family is closed to their child's deviant behavior and their child's less potential to become a leader. This condition is interpreted as the winning team and brother-in-law the regent as dishonesty to the regent/chairman of the party in politics.

The work culture of this Islamic-affiliated party depends on the chairman, namely the use of leader ethnocentrism. What the chairman/Imam and sub-groups in the party say is followed for the future economic interests of their family business. The commodification of votes is carried out by parties with money politics to prospective voters with a larger amount of money per person. In addition, this chairman has large business economic assets, so the economic interests of his family and relatives' businesses are prioritized. For that, he prefers to cooperate with the opposing team for the security of his business. Meanwhile, the 'ethnocentrism' of the majority of party members as members of NU/Nahdatul Ulama at the head of their party as well as NU clerics is used by opposing parties to carry out political cooperation by negotiating the winning of their executive candidates with hidden teams from Islamic-affiliated parties. The cooperative agreement for securing the Regent's business economy was carried out by the chairman and his team who secretly supported the opposing executive candidates, regardless 
of which party was the winning party and the ruler of the 15 legislative seats as well as the party carrying the female executive candidates and their deputy candidates. The party's internal demolition was carried out by the chairman and his team.

The use of this leader's 'ethnocentrism' is a commodification of the work culture of an Islamic-affiliated party by the party leader and sub-groups within the party that affects the future economic interests of his family's business. If the candidates for regent and deputy regent win, their business continuity is threatened. The commodification of votes begins when the candidate from his family does not receive a recommendation from the leader of the central party. Another commodification is giving money to prospective voters with a larger amount of money per person. The business owned by the Regent's family as well as the Party Chair and his team is in the field of education, namely the establishment of elite Islamic-based schools from the elementary, junior high, and high school levels as well as other fields while serving as regent. The control and development and safeguarding of its business economy in various fields can continue. For this reason, instead of using money as a commodity to support female regent candidates, it is better to support the 'prince of her son' who chooses an opponent. Because the opponent is the daughter of a former female regent whose economic power in business is very large until now. Even though the opposing regent candidates lacked leadership. His mother's role as a former regent was very large from a party with a national ideology.

The habit of the regent's relatives who carry out manipulative tactics through the politics of cooperation, namely by forcibly requesting project allocations to Bappeda and certain agencies. It even developed into a project broker. As a result, under pressure, Bappeda and other agencies were forced to give some projects to relatives of the regent. The working culture of the party through this project is seen as an economic interest and power. As a result, the business economy of the regent and his relatives was successful. The assets controlled by the regent are in the form of control of various business economic assets such as housing, hotels, industries, schools, and other assets. The hope of increasing the assets of the Regent is also owned by members of Islamic-affiliated parties. Expectations were high that he joined the party to gain additional economic power and gain power.

Hope to continue to get big projects in the future, to be given more money for consumption, to get another job. Consumption of regional head elections increased because there was consumption of money distribution for members and heads of special moneydistributing teams. As a case in point, one sub-district depends on what party the ballot is for, for example, the target number of voters is 500 people divided by how many sub-districts. The chairman plays by manipulating money, where the money for 500 people is not divided equally. Money is only given to 400 people. The rest is taken by the head of the special money-sharing team for personal profit consumption, even though they have earned their own money as a leader. Members also do the same. The politics of cooperation is carried out by them to compete and compete in a special team, by bringing recommendations from certain officials, certain brokers. So far, the habits of the regent's relatives manipulate and lobby and lie everywhere without shame, the important thing is that their money consumption needs are met.

\section{Discussion}

This paper has shown that there has been a controversy over the interpretation of the defeat of the executive candidate from the Islamic-affiliated party that carries him as well as the 
legislative ruling party in the district. The first group believes that their executive candidate will win because this party controls 15 legislative seats. The second group is not sure if the executive candidate wins. This difference in understanding creates obstacles in the effort to win the executive candidate from the winning party. The form of the controversy over the defeat of executive candidates from Islamic-affiliated parties is that the ballot boxes of supporters of female executive candidates turned to favor their opponents, the party leader and his team did not comply with the recommendations of the General Chairperson of the Islamicaffiliated Party to carry out activities to support their candidates, strengthening 'ethnocentrism' resulted in internal party decompression. The form of this controversy was influenced by the internal conflict of the Regent's family which resulted in internal party divisions, the giving of money from the house to house and during the recitation, half-hearted support by the chairman and the team from the carrying party to the candidate who received a recommendation from the general chairman of his party.

The Islamic affiliated party as the ruling legislative party turns out to be an executive candidate from the party that he has participated in so far does not guarantee his victory. Likewise, with citizens as voters, the arena for general elections and regional heads is eagerly awaited. Moreover, the need for money and the economy cannot be met with the enactment of PSBB/Large-Scale Social Restrictions during a pandemic. Economic opportunities for 'party people and officers' during the regent election, especially during a pandemic. Their habit of giving and receiving money. The Islamic-affiliated party which was split because of its ambiguous chairman implies that the community members as potential voters prefer the Regent candidate who gives more money, even though this candidate is young, inexperienced, and unmarried. However, they are less concerned about the capacity and potential, expertise and experience of the candidate for regent, which is important for the value of money received to meet socio-economic needs.

The politics of economic cooperation through the work culture of Islamic-affiliated parties in cooperation with national parties is a reciprocity in the economic process of giving and receiving money. The process is economic, namely the process of mutual reciprocity between the giver of money and the one who is given the money. Moreover, they do not have money during a pandemic. The election of regents was carried out during the Covid-19 pandemic. They are less able to work, both fishermen, casual workers, farmers, entrepreneurs, traders, lower-middle-class employees, and other workers. Meanwhile, middle-class workers experienced a decline in income. The defeat of an executive candidate from an Islamicaffiliated party that carries him is to prove that it is not a guarantee that the work culture of the party carrying it works hard for the victory of the candidate it carries.

This condition changes the map of the alignments of Islamic-affiliated parties to the opposing party. This defeat disappointed people who wanted change and were loyal to female executive candidates. Even though this female executive candidate has worked hard to campaign despite the PSBB during a pandemic like in Brazil, female executive candidates are working hard to raise campaign funds (Gatto \& Teme, 2020). Another impact on the sustainability of the new government and subsequent people's lives is that this winning regent/executive lacks experience in organizing and politics and expertise and leadership. But his mother was a former district head for two terms forcing her son to maintain his business and power. Other impacts on the sustainability of the new government and subsequent people's lives, such as the inauguration of a new regent without a representative, because this representative is a formality, even though this representative is from a large religious national party. The new regent changed his leadership status from a religious national party, where this leader was the son of a losing candidate for deputy regent to become an ordinary member of 
the district DPRD. Likewise, the head of the PKK and the party's Dharma Wanita is not the wife of the elected deputy regent but comes from a civil servant who serves in the local government.

There are informants, election officials, and voters who have been affected by Covid-19. During the preparation, implementation, and post-regent election process, several informants were exposed to Covid-19. Informants continue to carry out activities related to the election of regents. Vaccines have not been carried out in various regions, including the districts where the research is located. Even though information on the risk of activities carried out by the community during a pandemic has been spread through the media and digital environment. This information, among others, explained by Bernd Sebastian Kamps \& Hoffmann (2021), that Covid-19 has developed with various variants in various countries in the world and has caused victims to be exposed to Covid-19 and even died. Citizens from these various countries have started to be vaccinated along with the development of the discovery of various kinds of vaccines, although there are also vaccines that cause side effects.

The regent of this regency wants his power to be lasting and long-lasting so that his economic assets in the area are safe and undisturbed so that they can survive. Family conflicts continue to internal party conflicts. It seems that choosing and nominating female deputy executive candidates is just a ritual if the party participates in the regional head election. That's why he and his team who are samina wato'na support half-heartedly and prefer to demolish his Islamic-affiliated party. Moral responsibility to constituents or society holistically is relatively lacking. It also appears that ethnocentrism is being used, because the chairman and regent understand that the majority of his supporters are NU citizens.

The choice of most NU residents is based on their hopes for the future business economy. Various tactics were carried out to achieve central, regional, and local projects through the use of the party's work culture as he had done with his relatives during his 2 terms of leadership and the former Regent and his success team and members of his relatives for 2 periods as well. For this reason, the Regent wants the target of his party, which is affiliated with Islam, to be $100 \%$ victorious as the ruling party. Thus, the Regent's policy as the executive is not disturbed by the economic interests and power of the members of the legislature/DPRD because the 15 seats are controlled by the Islamic-affiliated party. In such conditions, it appears that the massive commodification of votes was carried out to meet the economic needs of the family business and relatives of the regent as well as to fulfill voter consumption during the Covid-19 pandemic. This party is not ashamed that its executive candidate lost.

The regent studied the experience of the working culture of the DPR, where the defeat of Islamic parties and Islamic-affiliated parties in the central legislature had an impact on the provincial and district/city legislatures. The number of legislative members who sit in the People's Legislative Assembly from parties based on Islamic ideology or affiliated with Islam is very small compared to parties representing religious national ideological bases. So that when making decisions on religious policies or laws (related to Islamic law) they are always defeated at the decision-making level because they lose votes when voting. An example of prohibiting the circulation of liquor in five-star hotels was not approved by the DPR's vote. So that almost all proposals related to Islamic Shari'a rules proposed by parties based on Islamic ideology and Islamic affiliated parties were lost when the decision-makers at the plenary session level in the House of Representatives.

\section{Conclusion}


The defeat of female executive candidates from Islamic-affiliated parties, winners, and legislative rulers in the district is influenced by the commodification of the work culture of Islamic-affiliated parties by utilizing the ethnocentrism of NU/Nadhatul Ulama residents, the business economic interests of the chairman of the Islamic-affiliated party with his family, internal family, and party conflicts bearer. The carrier party supports half-heartedly its executive candidate, who has obtained a recommendation from the central general chairman. Economic, socio-cultural, and power interests underlie the behavior of elite actors and their communities, not the economic and socio-cultural interests of the community/constituents. The executive (the regent who wins the Pilkada/Elected Regional Head) lacks the potential for skills and leadership and lacks organizational and political experience. But he was forced to run by his mother, the former district head of the region, for two terms to maintain his business economy and power.

Scientifically, the contribution of this research can be useful for the development of Anthropology, especially Economic Anthropology, because of the controversial phenomenon of the defeat of female executive candidates and their representatives from Islamic-affiliated parties as well as district legislators is analyzed from the perspective of Economic Anthropology. The limitation of this research is the analysis of one district only. For this reason, it is important for further research on how the economic behavior of the winning executives and their representatives and the economic behavior of the female executive candidates and their representatives who lose.

\section{References}

[1] Amri, Husni. 2018. Faktor-faktor yang mempengaruhi Kekalahan M. Amin dan M. Shaleh dalam Pemilihan Regent Kampar periode 2017-2022. JOM FISIP. Vol 5. No.1. Hal 1-15.

[2] Anggraeni, Ary, AG. \& Eka Wenats Wuryanta. 2020. Industri Religi pada Media online. Communications, 2(2), 61 - 73. DOI:10.21009/Communications.2.2.4.

[3] Bowskill, Sarah E.L. \& Jane E. Lavery. 2020. Eli Neira: Pursuing Community and Interconnectedness against the Commodification and Institutionalization of Culture in Chile. Bulletin of Spanish Visual Studies. 4:1. P 93-124. https://doi.org/10.1080/24741604.2020.172066.

[4] Bruntz, Courtney. 2020. Religion as Financial Asset: State Investments in Buddhism. Journal of Human Values. DOI: 10.1177/0971685820973189. P 1-12.

[5] Chandra, R., \& Walton, M. (2020). Big potential, big risks? indian capitalism, economic reform and populism in the BJP era. India Review, 19(2), 176-205. doi:10.1080/14736489.2020.1744997.

[6] Chapman, Rachel R. 2010. A Nova Vida: The Commodification of Reproduction in Central Mozambique. Medical Anthropology. 23:3. P 229-261. https://doi.org/10.1080/01459740490487107.

[7] CNN Indonesia. 2020. Pilkada Surabaya: 4 Penentu Kemenangan Eri-Armuji.

[8] Dharma, Ferry Adhi. 2018. Komodifikasi Folkor dan Konsumsi Pariwisata di Indonesia. Biokultur. Vol VII.No.1. 1-15.

[9] Gatto, M. A. C., \& Thome, D. (2020). Resilient aspirants: Women's candidacies and election in times of COVID-19. Politics and Gender, 16(4), 1001-1008. doi: $10.1017 / \mathrm{S} 1743923 \mathrm{X} 20000537$. 
[10] Hawari, Nadirsah. 2019. Tahaluf Siyasi dalam Praktik Politik Partai Islam di Indonesia. Migot. Vol. 43. No.2.

[11] Hariyanto, Didik. 2018. Commodification of Umrah worship in Umrah travel agency capitalism in

Indonesia. http//repository.unair.ac.id/id/eprint/80353JURNAL_Dis.S.13/18 Har k

[12] James, T. S. (2021). New development: Running elections during a pandemic. Public Money and Management, 41(1), 65-68. doi:10.1080/09540962.2020.1783084.

[13] Kalaf-Hughes, N., \& Leiter, D. (2020). That woman from michigan: How gender resentment shapes the efficacy of stay-at-home policies. Politics and Gender, 16(4), 983-990. doi:10.1017/S1743923X20000392.

[14] Kamps, Bernd Sebastian, Hoffmann. 2021. Covid Reference. Ed 6. Hamburg: Steinhauser Verlag. www.CovidReference.com.

[15] Kaur, M., Verma, R., \& Otoo, F. N. K. (2021). Emotions in leader's crisis communication: Twitter sentiment analysis during COVID-19 outbreak. Journal of Human Behavior in the Social Environment, doi:10.1080/10911359.2020.1829239.

[16] Noer, Deliar. 1999. Mengapa Partai Islam kalah? Perjalanan Politik Islam dari pra pemilu. Dalam Deliar Noer \& Kuntowijoyo (eds). Islam dan Politik. Jakarta: Alvabet. Hal 3-10.

[17] Okoli, Al-Xhukwuma Uhembe, Ahar Clement. 2014. European Scientific Journal. Vol. 10 No. 14.

[18] Piazza, Kelly Senters \& Gustavo Diaz. 2020. Light in the midst of chaos: COVID-19 and female political representation. World Development, 136. DOI:10.1016/j.worlddev.2020.105125.

[19] Peteovic, John E and Bedrettin Yazan (eds). 2021. The Commodification of Language: Conceptual Concerns and Empirical Manifestation. London \& New York: Routledge.

[20] Riyanto, Agus. 2020. Mengapa Partai Islam belum pernah menang?: Path Dependence Repetition Kekalahan Partai Islam Indonesia dalam Pemilu Legislatif 1955 hingga 2019. Jurnal Politik Profetik. Vol 8 No 2. Hal 186-217.

[21] Roosvall, Anna. 2019. Religion, Globalization and Commodification in online world news slides hows: the dis/connection of images texts. Social Semiotics. 26:1. P 76-93. DOI: $10.1080 / 10350330.2015 .1059581$.

[22] Schedneck, Brooke. 2014. Meditation for Tourists in Thailand: Commodifying a Universal and National Symbol. Journal of Contemporary Religion. 1 29:3. P 439-456. DOI: $10.1080 / 13537903.2014 .945728$.

[23] Sinha, Vinneta. 2014. Commodification of Religion and The Religification of Commodities, Youth Culture and Religious Identity. Religious Commodification in Asia, Marketing Gods. New York: Routledge.

[24] Thadi, Robeet, Rifki Aditia, Novaldi. 2019. Commodification of Religion and Culture on Television Advertising. Multicultural Education. Vol 5. 109-116.

[25] Uyun, Zafirah Quroatun. 2015. Komodifikasi Tokoh Agama dalam Dalam Tayangan Iklan Televisi: Studi Kasus Ustadz Maulana dalam Iklan Operator Seluler Telkomsel Versi Haji. al-'Adalah. Vol.48.No 2. Hal 177-194.

[26] Yi, J., \& Lee, W. (2020). Pandemic nationalism in south korea. Society, 57(4), 446451. doi:10.1007/s12115-020-00509-z.

[27] Zuber, Abdullah, Achmad Mujab Masykur. 2020. Apapun yang terjadi kami tetap melayani (Studi Fenomenologis mengenai Pengalaman Calon Kepala Daerah yang kalah dalam Pilkada). Jurnal Empati. Vol 8. No 3. Hal 158-168. 